\title{
'One does not take sides in these neutral latitudes': Myles na gCopaleen and The Emergency
}

\author{
GERMÁN ASENSIO PERAL* \\ Universidad de Almería (Spain)
}

Received: 06/02/2017. Accepted: 06/10/2017.

\begin{abstract}
The years of the Second World War (1939-1945), a period known as The Emergency in Ireland, were pivotal for the development of the nation. Immediately after the outburst of the war in the continent, the Fianna Fáil cabinet led by Éamon de Valera declared the state of emergency and adopted a neutrality policy. Brian O'Nolan (19111966), better known as Flann O'Brien or Myles na gCopaleen, wrote a comic and satirical column in The Irish Times entitled Cruiskeen Lawn (1940-1966). In his column, O'Brien commented on varied problems affecting Dublin and Ireland as a whole. One of the many topics he began discussing was precisely Ireland's neutral position in the war. Therefore, this paper aims at examining Ireland's neutral position in the war as seen through a selection of columns from Cruiskeen Lawn, devoting special attention to the oppression of censorship and the distracting measures developed by de Valera's government.
\end{abstract}

KEYWORDS: Brian O’Nolan, Flann O’Brien, Myles na gCopaleen, Cruiskeen Lawn, Second World War, Ireland, censorship, propaganda.

\section{INTRODUCTION}

The years of the Second World War (1939-1945), a period officially known as The Emergency in Ireland, were of crucial importance both for the country itself and for one of its most prominent emerging writers, Brian O’Nolan (1911-1966)_better known as Flann O’Brien, and Myles na gCopaleen, among many other pseudonyms. ${ }^{1}$ On the one hand, for Ireland, it meant a real turning point in its history, or a watershed, as Brown (1981) puts it.

*Address for correspondence: Germán Asensio Peral. Facultad de Humanidades, Universidad de Almería, Spain; e-mail: german.asensio@ual.es 
The government's decision of remaining neutral, although slightly and covertly inclined in favour of the Allied powers, resulted in tentative national safety according to Roberts: "it protected the Irish people from the perils of war, asserted the country's sovereignty and independence from Britain, and, crucially, maintained the unity of the state at a time of great national danger" (2000: 165). Regarding O'Nolan, on the other hand, the general view has been that those years signalled his rise to, and subsequent downfall from, literary excellence.

His first and best known novel At Swim-Two-Birds was published by Longman in 1939 to intellectual and literati acclaim but the eruption of the war on the continent seemed to put his talent on hold: in 1940, Longman's London warehouse was destroyed by German bombs and At Swim-Two-Birds would sink into complete oblivion for almost twenty years. By 1940 he had already finished his second novel, The Third Policeman, which was rapidly rejected by Longman adducing that its plot abused of surrealism and fantasy (Cronin, 1990: 111). The novel would not be published until 1967, a year after his death. After this silent and at the same time ostensibly harrowing disappointment, in October 1940 O'Nolan was offered the opportunity to work as a columnist for The Irish Times as a result of a succession of witty and derisive letters to the editor on Patrick Kavanagh's poem "Spraying the Potatoes". The column he was meant to write several days a week was to be called Cruiskeen Lawn and it came to occupy a regularly visited space on the pages of The Irish Times for twenty-six years (1940-1966). It was then when, as many readers and critics alike have claimed ${ }^{2}$, Flann O'Brien's effervescence dissolved; or, rather, that Myles na gCopaleen - the pseudonym he used for Cruiskeen Lawn, The Poor Mouth and other occasional writings - put his older brother in a twenty-two-year coma from which he woke up without either genius or imagination $^{3}$.

Be that as it may, the war seems to have played a paramount role in O'Nolan's literary career: it cut short his early dreams of becoming an established published author while simultaneously introducing the possibility of a certainly less specialised yet constant readership through Cruiskeen Lawn. Few critics have tackled the effects of the wartime period on O'Nolan despite its relevance for the author's life and career, or the ways he approached the conflict. The most notable examples are Taaffe's (2008) examination of the early years of Cruiskeen Lawn or, more recently, Flynn's (2017) study on the column and Japan during the Second World War. Rather, critics seem to have mainly focused their analysis of that particular period of his career on analysing At Swim-Two-Birds, The Third Policeman and, less frequently, An Béal Bocht (1941) from manifold theoretical points of view. Some studies of the complex relation between O'Nolan and censorship — which played an important part not only during the war, but throughout all of O'Nolan's writing careerhave been carried out, such as those of Hopper (2000, 2009) and Long (2014), but they lack sufficient insight into the World War II time frame. 
This article aims at shedding some light on such important interstitial questions in O'Nolan's career: how did the period of The Emergency and its consequences in Dublin daily life affect his writing? What were O'Nolan's thoughts on how the official ideology reshaped the image of the war and how was it perceived by the Irish people? Although social, cultural and political circumstances prevented a fully-fledged and overt response to The Emergency, O'Nolan's committal to circuitously satiric modes of expression demonstrated a mounting concern about the state of the war, both in Ireland and elsewhere.

These questions will be answered by examining a short selection of the columns produced during the early years of Cruiskeen Lawn and published under the pseudonym Myles na gCopaleen. The corpus selected for this article consists of six columns, which share the same thematic issue of wartime years in Ireland, published between 1940 and 1947. The columns have been quoted from their original versions published in The Irish Times during The Emergency.

\section{THE EMERGENCY AND O'NOLAN'S EARLY CAREER}

It was very difficult for any of O'Nolan's wartime opinions to make it to print unscathed. After declaring Ireland's neutral position to the world - a decision which, according to Hachey (2002), has become the flagship of Irish foreign affairs - one of the very first things the then Taoiseach Éamon de Valera (1882-1975) did was to establish an obdurate censorship apparatus that hovered threateningly over the whole of the public opinion. Its effects were multifarious: "reports of the Holocaust were suppressed, newsreels were banned, children's games were seized and the expression of opinions on the war and Ireland's neutrality was strictly controlled" (Ó Drisceoil, 2000: 151). In actual fact, the de Valera Administration was assisting the Allies under-the-counter in many ways; for instance, as Murphy precisely notes, "Ireland provided valuable meteorological information and navigational facilities, extended preferential treatment to captured or stranded Allied military personnel, and even participated in joint military manoeuvres" (2000: 15). However, they did not avowedly express their support either in terms of political identification or in military actions, nor did they allow the Irish people to have a well-formed opinion of what was happening offshore. The media were officially compelled to broadcast objective, innocuous and antiseptic facts and were thus forced to obviate any detail that might have contributed to channel public opinion towards one side or the other ${ }^{3}$.

Narrowing it down to his position as a columnist for The Irish Times, it became even more difficult for Myles to openly express his views due to the newspaper's overt pro-British tendency. More than once several of its editorials were banned and R.M. Smyllie, by then editor of the newspaper and drinking companion of O'Brien at The Palace Bar, continuously 
provoked the censors with comic accounts of the war, actions that earned the newspaper a full censorial examination of each issue from December 1942 until the end of the war (Ó Drisceoil, 2000: 160). The fact that de Valera's neutrality was laxer than officially stated was known to a certain degree by the Irish people and the British government, as Smyllie later thoroughly explained in an article entitled "Unneutral Neutral Ére" (1946), published in the American journal Foreign Affairs. Be that as it may, scholars have recently perceived how Cruiskeen Lawn managed to deflect, if partially, censorial pressures within the newspaper.

[L]inguistically and programmatically apart from the rest of the paper, the format of Cruiskeen Lawn suggests a space of play rather than reportage or advertisement. Yet this peripheral status allows the column to evade the official legal limits put on wartime commentary. Using quotation, translation, allusion and pun to engage with events officially under the purview of the main newspaper, the column becomes an increasingly active part of The Irish Times, offering a more incisive and provocative engagement with contemporary events than the editorials or articles. (Flynn, 2017: 79)

This was a rare case. Overall, there were many drawbacks for Irish writers at the time in terms of publishing opportunities. Apart from O'Nolan, other literati such as Patrick Kavanagh, Sean O'Faolain, Frank O'Connor and Peadar O'Donnell struggled for creative independence and suffered the effects of censorship on their political opinions. The general atmosphere was thus one of isolation and stagnation: they "wanted the freedom to produce [a literature] of their own devising" (Wall, 1995: 233), to blur Irish literary borders and transcend to the European scene where they could circulate their work internationally. Indeed, as Brown notes, "no writer could imagine making a living on Irish sales alone" (1981: 174) and a cocktail of merciless censorship, restrained communications and London's occasional resentment towards Irish writers on the basis of their neutrality painted a discouraging general picture. Nevertheless, these social and political obstacles were eventually unsuccessful in preventing them from voicing their mind. What all of these writers had in common, especially O'Nolan and Kavanagh, was that "they felt a certain public vocation for the writer: a right to speak out and strike stances about their society, whether or not society was listening" (Brooker, 2014: 93). It may be assumed, then, that censorship conspicuously affected O'Nolan at the outset of his career, preventing him from publishing a substantial amount of what could potentially stand as politically detrimental material in Cruiskeen Lawn. "Myles na gCopaleen", Cronin writes, "was also subject to censorship of any views or preferences he might have expressed about the outcome of the war" (1990: 131). Yet it is also worth noting that his relationship with censorship was decidedly ambiguous. Hopper (2000) examines the excruciating extent to which O'Nolan went to render At Swim-Two-Birds suitable for publication by means of an aptly crafted metonymic discourse. This was far from being the case with his fourth (third in order of publication) 
novel The Hard Life (1961). Neil Murphy argues that "there appears to have been some desire, on O'Brien's part, to attract notoriety with The Hard Life” (2011: 150). The general feeling has been that this novel was primarily designed as bait for the censorship board since by then O'Nolan, as Myles, was a fairly notorious personality in the newspaper world. The reason for this seemingly literary suicidal desire was simply a matter of prestige: "there were [...] so many that to be censored was considered something of a mark of distinction [...]. Nearly every professional Irish author had had a book banned and O'Nolan's gleeful anticipation of the prospect makes it clear that he was anxious to join the club" (Cronin, 1990: 234). Therein lies the ambiguity of censorship in O'Nolan's career: during the war, censorship was pernicious for Cruiskeen Lawn and O'Nolan because the column was a constant, albeit scant, source of income; for the novels, however, it became an unfulfilled necessity over the years since unbanned novels paradoxically affected O'Nolan's recognition as a writer in a negative way.

O'Nolan, who had abandoned any hopes of an international career after the rejection of The Third Policeman, published An Béal Bocht, a satirical novel in Irish dealing with the excesses of Irish admirers and scholars. A novel written in Irish implied that he had geared his attentions - temporarily, at least - towards a more local audience, something to which the early success of Cruiskeen Lawn definitely contributed. This did not mean, however, a complete dissociation from the difficult European reality: he kept an earnest interest in the progression of the war and remained well informed en petit comité by people like Smyllie, who enjoyed ready access to unfiltered information. His options of eschewing the censors' attention and making his opinions on that information public were nevertheless very limited given the close scrutiny under which The Irish Times was. He had to devise, in a subtler style than that of his editor, a way of manifesting his views on the state of the war and the country's role within it. O'Nolan, as all journalists and intellectuals at the time, had been put in a straitjacket he could not easily free himself from, and as Wyse Jackson perceives, his tone "darkens alarmingly" (1999: 12) during the war years. As the articles on the war and the neutrality policy adopted by de Valera selected for analysis will demonstrate, a modulation from an incipiently demure and veiled sarcasm to frank and clear-cut retaliation by the end of the conflict can be observed; this proves that censors seemed to be loosening their hold on journalism. Such outspoken post-war comments as the following one contrast enormously with those produced mid-conflict: "Well, I see ye have your Oireachtas on again, with speeches, pipe bands, songs, story-telling and chess competitions. God speed the work, I hope it keeps fine for ye! No shadow of the atom bomb there, I'll go bail!" (na gCopaleen, 1946: 2). In fact, as Flynn writes regarding Myles' engagement with Japan's role in the war, "Cruiskeen Lawn's undoing of its own marginality is accompanied by its insertion of Ireland into world politics, achieved through suggestion rather than direct statement" (2017: 79). The merriness and nonchalance of a State, deeply preoccupied with Gaelic localisms in those 
years while the rest of the world was still grieving deep after the atomic bombings of Hiroshima and Nagasaki (6-9 August, 1945), was relentlessly criticised by Myles, thus detaching himself from what he seemed to think was an exaggerated 'neutral' position on the part of the government. During the war, some of its members seemed to be overly absorbed by comparatively irrelevant problems such as the banning of controversial writers like Eric Cross and Kate O'Brien rather than concentrating their attentions on tackling serious defensive issues at home (Brown, 1981: 197). There was, indeed, a generalised dismissal and discouragement of anything that might challenge the social and cultural stability that de Valera cherished and was intent on preserving. This official perseverance also extended to education, as Gillespie has remarked: "Mainly shaped by pre-independence educations, themselves shaped and executed by the Catholic Church, the generation in power inevitably tried to insert their cultural and political agenda into a framework modelled on their own educational backgrounds" (2014: 174). The government, particularly during wartime, was adamant on promoting an obsolete variety of Irish culture which failed to come to terms with the reality of its time. De Valera's famous 1943 St. Patrick's Day speech "The Ireland that we dreamed of", which commemorated the $50^{\text {th }}$ anniversary of the creation of the Gaelic League, was the epitome of this tendency. As will be observed in the analysis that follows, "for O'Nolan, Ireland is and was predicated on fakes, copies, farce and anachronisms" (Long, 2014: 109). This might explain his reservations towards any policy espoused by de Valera's government, including neutrality during the war.

\section{MYLES, CRUISKEEN LAWN AND THE EMERGENCY}

For Hopper (2000: 122), "writers will always find ways of circumventing censorship through imaginative processes of invention, euphemism and circumlocution, or by resorting to encoded discourses which substitute signifying symbols for what is forbidden". This was the case with Myles during the war. Being unable to fully express his views on any aspect regarding the war in itself save from very oblique and extremely comic references to any of the sides involved, he tended to draw his readers' attention to what was readily and more easily perceptible by them; that is, the local effects of the war. Derived from this, Myles also commented on the hypocrisy, inconsistency and even unreasonableness of many of the measures taken by the State to ensure a minimum of social and economic welfare during The Emergency. By the beginning of the war, for instance, one of the many different means of income the State had been devising for decades since its inception was tourism. Ireland was a newly-born country and from 1929 onwards, the different governments incessantly increased the budget for tourism at all levels, promoting the country's mythical beauty through many different publications (Zuelow, 2009: 21). During wartime, Ireland's neutral condition in the 
conflict was probably seen by officialdom and travel agencies as a potentially effective way of attracting western visitors who might be afraid of getting any closer to the disrupted continent, as well as for British people who "choosing to protect themselves from wartime austerities in Britain, and the bombing of British cities, found no better haven than the cushioned existence of the Irish country hotel" (Wills, 2007: 244). This, combined with de Valera's zeal to revive Ireland's Celtic past and use it as a strategy for national selfdetermination, was the perfect target for Myles' repressed, albeit equally derisive, satire:

I notice that the current issue of Irish Travel is adorned with the Irish supertitle Cuaird Faoi Éirinn. So far as my knowledge goes, this means nothing more or less than 'Travel Under Ireland'. The suggestion seems to be that the Irish Tourist Authority is taking note of the times we live in and is arranging underground tours for scared visitors. Such enterprise deserves (and gets herewith) unqualified commendation.

I cannot dismiss from my mind the picture of a group of bright-faced Americans being carefully lowered through a man-hole or excavation in O'Connell Street and emerging on to some quiet thoroughfare in Waterford -. (na gCopaleen, 1941a: 6)

One could effortlessly observe that not only is Myles poking fun at the ineptitude of some Gaelic publicists, but he is also making severe and serious implications about Ireland's presupposed safety. Could any tourist or visitor feel minimally safe in a neutral country during the war? For his part, de Valera maintained a resolute confidence that neutrality equalled safety, even though the truth was that a collateral German invasion might have become a reality had Hitler's Blitz been successful in Britain between 1940 and 1941 (Brown, 1981: 171). This might indicate that Myles distrusted neutrality and saw it as puerile escapism from the war which, in turn, was also fed by de Valera's diversion of attention to arguably local, inconsequential matters such as the importance of the country's Celtic past. In actual fact, Myles invokes Gaelic language issues in the same column as a means of avoiding the censor's radar, making important but cloaked claims on the government's course of action:

The Gael wakes up in the morning and grabs his favourite newspaper. Vast letters on the news page inform him that (say) Bardia has been captured by the British ... and then he turns the page wearily in search of some smooth emollient Gaelic. After a lot of poking in the paper's backyard, he finds something like this:-

The intelligence has been made naked that the city Bardia has been invaded by Saxons this Tuesday that went past.

The astonished Gael realises that he is regarded as a cretin. (na gCopaleen, 1941a: 6)

The ungrammatical Gaelic construction and Myles' disproportionate complaint is but the external layer of a more complex message. There are slight nuances of meaning between 
the words "captured", present in the hypothetical English version, and "invaded", belonging to the Gaelic version, implying that the government might be betting on two horses at the same time whilst destabilising Britain's image on the eyes of Gaelic speakers. This was not the first time Myles made use of the official state language as a means of smuggling in his most contentious political and social material. Taaffe claims that "on his Irish days, Myles could ridicule the quaintness of the language revival, safe in the presumption that while his audience would be proficient in the Irish language [...] they were unlikely to hail from the more extreme readers of the revival movement" (2008: 128). Such is, indeed, the linguistic strategy at work in this column. More important is the fact that the Battle of Bardia was fought between January 3 and 5, 1941; that is, between a Friday and a Sunday-Bardia was never invaded on a Tuesday. Through his position on the newspaper, Myles was definitely aware of the progression of the war and there are many chances that he committed such a mistake on purpose to hint at the unreliability of Irish news and the government's unobstructed tampering with war facts. To clearly set out the censor's agenda, he refers to both sides as "the-friends-we-know-are-by-our-side-and-the-foes-we-hate-before-us" (O'Brien 1999: 24) and seems to position himself in favour of the Allies, thinking that regardless of their sombre common past, Ireland should take action and side with Britain: "What we want is a little sympathy, a spirit of give-and-take, a readiness to pull together and forgive each other's failings, a realisation of our common humanity" (1999: 25). In this article, the heavily-charged political content is substantially deflated and intentionally reshaped as Gaelic household trivia. This strategy is present in virtually all the wartimerelated columns and was, according to Coulouma, a marked feature of the column as a whole: "since the constant use of anecdotes presents the column itself as harmless banter, it brings down the serious, political news to the level of anecdotic (and often comically absurd) fun" (2011: 170).

The Emergency, however, was not a battle fought only in newspapers, novels or plays by the literati or in the Dáil by the de Valera Administration. Its scope covered and enshrouded dome-like the whole of the population of Ireland and their daily lives underwent drastic changes that would contribute, for better or worse, to shape modern Irish mentality. Thanks to de Valera's determination of remaining politically neutral and his firm belief in a financially self-sufficient Ireland, daily living conditions were not as severely undermined as in the rest of Europe, where entire countries went through more than five years of stagnation, economic misery, decimating hunger and the towering sorrow of millions of war casualties. This is not to say that the country was entirely unaffected by the war: Ireland did most certainly suffer the side effects of production shutdown in Europe at all levels. Dublin in particular, Wills asserts, "was a city of contrasts. The tempting availability of luxuries was combined with the real difficulty of getting hold of staples of everyday life" (2007: 245). Commodities which were normally affordable for the majority of the population such as 
bread, tea, sugar, paper, tobacco and fuel began to be severely rationed from 1942 onwards and an increasing imbalance between the decrease in exports and the increase in price of imports — and their reduced availability — became rather common (Brown, 1981: 176). And on top of that, these commercial obstacles produced a knock-on effect: food shortages generated widespread malnutrition for those who could not afford to keep up with raising prices and some sectors such as transportation were especially affected due to insufficiency of petrol: there were "7840 private cars licensed in Ireland in 1939, falling to a mere 240 in 1941 as a result of The Emergency”, as Ferriter recounts (2005: 373). While Dublin was not a paradise whatsoever, it was in a much better condition overall than other European capitals.

By the beginning of the war O'Nolan was a prominent thirty-year-old man with a job in the Civil Service and his column-writing was also remunerated, so it is very unlikely that war shortages interfered with his daily habits despite his family responsibilities. He was very aware of the rationing situation nonetheless and during the whole of The Emergency he set out to comment, in a mocking and satirical tone, on the ways the government and the population were handling shortages. Many of the columns devoted to this issue stem from an informative policy adopted by the government espoused by different sectors of society, such as the Church: the first years of the war saw an increase in the publication of manuals which recommended measures to making the most of the resources at hand; they usually contained useful tips on cooking and other household chores (Wills, 2007: 242-243). Myles satirically echoed these curious proposals, as it happens in the following column, entitled "Home Hints":

Be sure to cut this out, paste it on cardboard, and hang it up in a prominent position in the kitchen. My illustration explains what the Gas Company, the Electricity Supply Board and the Government expect you to do in these difficult times about your shaving water. In nearly every household vast saucepans of clothing or potatoes are boiled every morning. Your task, no less than your duty, is to fit the saucepan with the catchment apparatus illustrated. The water that boils over is thus neatly husbanded and deposited in the waiting mug. When the mug is full you carry on with your shaving, or make yourself a refreshing cup of cocoa if you happen to be a lady. (na gCopaleen, 1941c: 5).

The title of the column curiously resembles radio programmes broadcast during the war offering advice on shortages such as For the Houskeeper (1942) and books such as Homecraft Book (1944). There were gas and electricity shortages during The Emergency as well and Myles sought to offer a comic solution for them: recycling the already vaporised water for other activities such as shaving or preparing cocoa.

During the following years, Myles kept on dropping this kind of silent bombs which on the other hand seem to follow a clear pro-Allied discourse. In particular, August 1941 seems to have been an unusually fruitful month for Myles regarding war material. The very same 
day "Home Hints", the previously discussed column, was published, Cruiskeen Lawn included an extra column which happens to strongly contribute to forming a general picture of Myles' ideological orientation at the time. This article, entitled "A Letter from the Interior", deals with two semi-fictional Corkmen, Marshal Tim O'Shenko ${ }^{4}$ and one alleged brother, Tomoshenko. Speaking as Myles, he claims to have known Tomoshenko, who told him more than once about his brother's comments on the ideological conundrum on the continent. He recounts the fictional conversation as follows: "'I've had a letter from Tim,' he said, 'and he takes a very poor view of what is happening in Germany. He says that there will be a world war in seven years, if not sooner. He has joined the Red Army as a private" (na gCopaleen, 1941c: 5). Although this column was produced after the outbreak of the war, Myles was aware of the situation in Germany beforehand. The stark censorship apparatus banned any possible explicit reference to Hitler's atrocities (Ó Drisceoil, 2000: 154) but Hitler's rise to power in 1933 did reach Ireland. Also, O'Nolan's knowledge of the German language and culture and his presumed trip to Germany between the late months of 1933 and June 1934 - where he was allegedly beaten in a pub over some offensive comments on Hitler (Cronin, 1990: 74) - might have provided him with a first-hand overview of the nascent stirrings of Nazism. Be that as it may, the statement above on the political state of affairs in Germany at the time is considerably straightforward and most likely overlooked by the censors as their hold on The Irish Times was perhaps not as strong as during later stages of the war. Later in the same column, Myles took the opportunity to make an important cutting remark on neutrality: "One does not take sides in these neutral latitudes, but I think most of my readers will join me in expressing the hope that we will yet see both Tom and Tim O'Shenko back in Ireland safe and sound, matching their military wit against General Bogey on the Hermitage terrain, and fighting with the same indomitable will to win. Ireland never had to more likeable sons" (na gCopaleen, 1941c: 5). His comments were always couched in a cloak of irony, hence it is very difficult to discern whether he really meant what he said or not. A plausible interpretation of this passage, regardless of his obvious reproach of neutrality and censorship, is that he is probably making an oblique reference both to a desirable Allied victory and to the over 50,000 voluntaries from Ireland whose participation in the war de Valera was so intent on concealing from the public (Ó Drisceoil, 2000: 152).

As can be seen, Myles examined the whole question of neutrality and ideological repression focusing as much as he could on controversial topics in a very implicit, comic and metonymical manner so as to avoid the censor's eye. He toyed alternatively with ideological questions and with the role censorship was playing in Ireland, and the following column to be analysed is an excellent example of the latter. On September 26, 1941 he started a sequence of columns addressing Dublin's cultural state, especially with regard to theatre. Many have agreed that "despite the feelings of isolation that 'The Emergency' engendered, the years 1939-45 were a productive time in Irish letters" (Wall, 1995: 235) and theatre in particular 
"saw a healthy growth in an amateur dramatic movement" (Brown, 1981: 179). The result was a period of splendour for Dublin dramatic circles resulting in higher records of attendance to local theatres like the Abbey, something that Myles famously recounted very sardonically in his series of columns "WAAMA, etc". It must be taken into account that while there was an increase in dramatic activity, this did not mean that theatres became forums on the state of the war: the same as with anything intellectually-related, the hand of censorship quickly swept over anything that might provide any ideologically-oriented information on the conflict from overseas. Again, making up another fictional event, he discussed a play supposedly commissioned by the Abbey whose rehearsal was eventually cancelled and no explanations were given:

In another play there is a desperate storm at sea. Masts, funnels and lascars are carried away by the roaring sou'-easter. The schooner ultimately founders on the stage with all hands, the captain sea-dog that he was, reading extracts from The Irish Times leading articles as he is engulfed in his noble death.

The Panzercorps, coping-stone, raison d'ètre and sine qua non of the strategy devised by the German Obersteheersleitung, will, according to the Führer, achieve so oder so a decision in the east.

... Nevertheless, the piece was turned down. No reasons were given, but I heard through a friend that it was considered unsuitable for a Dublin audience because the cast did not contain a young girl who has been done wrong, a tyrannical ecclesiastic and an impecunious gentleman with a Dublin accent. (na gCopaleen, 1941d: 2)

Such "leading articles" were probably those written by the editor of The Irish Times, Smyllie who, according to Jackson, "evaded the Censor by cheering on the allies as neutrally as he could - or, as Myles put it, "played with his Panzerdivisionen"” (1999: 9). And of course, the fictional play he referred to in the column was not rejected on grounds of unsuitability for Irish audiences but because it supposedly contained idiosyncratic material that might sway Irish public opinion on one side of the conflict or the other - there was no way Hitler would be called Führer in the public press. This piece is a masterstroke on the part of Myles as it succeeded in fulfilling a twofold purpose: on the one hand, he attacked censorship in a roundabout way by unveiling the reasons for literary pieces being censored or turned down in Ireland ${ }^{5}$, and on the other hand, a comic abasement of the local and provincial tastes of audiences at the time.

These theatre-goers, whose number grew during The Emergency (Wills, 2007: 305), were practically anybody who could afford it; that is, the middle and high echelons of the metropolitan society. For Myles, many of them fell under the category of 'Plain People of Ireland', who in turn were keen on theatre just because it was fashionable at the time Myles undoubtedly thought them to be the prime victims of de Valera's web of political lies, the biggest one being the creation of his ideal of a Gaelic Ireland, "with a decent way of life 
deeply rooted in a rural past and in a frugal sufficiency" (de Paor, 1979: 22). In a particularly powerful column published on 15 February 1943, Myles addressed this population in a highly ironic tone, describing the ideally meek people de Valera wanted to populate this new Ireland:

We are extremely nice people. A humble community of persons drawn together in our daily round of uncomplicated agricultural tasks by the strongest traditional ties .... Our conversation — gay, warm and essentially clean-is confined to the charming harmless occurrences of every-day life [...] The wild and morbid degeneracy of the outer world does not concern us .... A wide and benevolent administration protects us from backin' alien horses, I beg your pardon, bacchanalian courses [...] What is called 'news' (by which one means the perverted sensationalism of the yellow press) does not concern us. We are not amused. Rumour (that recumbent jewel or lying jade) once had it that a war was going to break out. Nothing ever came of it, of course [My emphasis] [sic]. (na gCopaleen, 1943: 3)

That is broadly the picture de Valera might have wished to paint: an introspective Ireland, sufficiently narcissistic to look at itself in the mirror and smile with pride but not conceited and greedy enough to partake of the vices and the corruption of the continent. Discussing the government's ideal model of country is not within the scope of this paper, but the ways those ideals contributed to the image of the war as perceived by Irish people are indeed our focus of analysis. This passage convincingly depicts the mental paralysis of a country which, for the sake of commodity, security and comfort, decided not to meddle in a conflict which might have changed the future of the human race. The pastoral Eden that De Valera wove together speech after speech was a fatal ideological blow to open-minded and metropolitan writers such as O'Nolan, who found extremely appalling "the alarming number of Irishmen, in the last century and in the present, who were willing to conform to these stereotypes" (Kiberd 1996: 503). Special emphasis has to be laid upon the expression "backin' alien horses", which of course refers to the possibility of the people taking any ideological turn in the middle of a precarious and teetering political situation, something contrary to de Valera's agenda. In this column, his irony takes on a defeatist nuance: his statement is no longer a shot in the dark, so to speak. Rather, he seems to openly accept that, as he wrote in another censorship-related column, "it is the same stuff all the time. You just change it round a bit" (O’Brien, 1993: 84).

\section{CONCLUSION}

The Cruiskeen Lawn excerpts selected for analysis throughout this article aptly trace and demonstrate the progression in Myles' rhetoric during the war: While the early 1941 columns 
approach, the 1943 and 1946 articles display growing disenchantment and aggressive irony towards war policies in Ireland. Moreover, the articles analysed illustrate the creative energies put into misleading censors and filtering his observations on the war and the official approach to the conflict.

In light of what has been said so far, then, it might then be questioned whether de Valera won his war by using censorship and neutrality or whether O'Nolan and his contemporaries were successful in their struggle for self-expression. Nowadays there is general academic consensus that Irish arts, especially literature, flourished during wartime, but the actual fact is that the oppressive censorship of the time cast thick clouds of doubt over their expectations. What is clear is that, for the simple reason of being well-known Dublin literati, they were constantly in the spotlight, both by the censorship apparatus and by other foreign and national colleagues. Wills (2007: 75) makes reference to Louis MacNiece's account of a short stay in Dublin during The Emergency, when he had the chance of spending a day with O'Nolan and the rest of The Palace crew. MacNiece detested these intellectuals' escapism and their indifference to the desolate status of the continent, claiming that they were more worried about Irish revivalism than about the wasteland Europe was turning into. While the decreasing flux of news on the war and the unpartisan way in which it was told might have engendered insensibility on their part, most likely MacNiece's picture of them was inaccurate, for at least O’Nolan, as this article has tried to show, was far from being disinterested or unconcerned about the ongoing conflict; in fact, his loathing of de Valera's political interest in the Irish language - one of the pillars of his political critiqueeven contradicts MacNiece's. For more than five years his columns turned upside-down the Dublin of the time, targeting above all the pretences and charades he found in the Irish government's role in the conflict. The de Valera administration was, in Myles' opinion, more preoccupied with addressing ideological dominance at home than with, as he termed it in his 15 February 1943 column, "the wild and morbid degeneracy of the outer world"; that is, the Second World War. Based on his daily outright rejection of de Valera's policies and his mockery of the measures taken by the State to counter shortages, one could safely assume that neutrality was not particularly favoured by Myles. The impression given is that he perceived de Valera as someone devoting his efforts as Taoiseach to devising a selfperceived desirable rural future for his country under the cover of neutrality instead of taking part in a battle for the fate of all humanity. O’Nolan certainly knew that being a semi-public figure and having continuous audience was synonymous of expressive restraints and thus weathered his way through the censorial storm as best as he could by means of a surreptitious rhetoric and ultimately subversive satire. 


\section{ACKNOWLEDGMENTS}

The research of this project was supported by CEI Patrimonio (University of Almería).

\section{NOTES}

1 This article will follow the naming system introduced by the International Flann O'Brien Society and used in the majority of contemporary publications on O'Nolan: Brian O'Nolan is used when the man, or his works in general, are referred to. When a particular text is being discussed the pseudonym under which it was published is used.

2 Most notably, Kiberd (1996: 512), who wonders whether O'Brien's genius might have been better exploited if he had had the time and energy that Cruiskeen Lawn drained out of him daily, eventually arriving at the conclusion that O'Brien's career would have actually been far more productive.

3 Cruiskeen Lawn is starting to slowly receive all the attention it merits. See, for instance, Young (1997), Brooker (2005), Taaffe (2008), Coulouma (2011), Gillespie (2014), McCourt (2014), Harris (2016), and Flynn (2017).

4 For further reading on Ireland and the Second World War see Hachey (2002); Girvin (2006); Kennedy (2008); McMahon (2008); O'Halpin (2008) and Wood (2010). For a more detailed account of censorship during The Emergency, see Coles (2006), Jones (2011) and Ó Drisceoil (1996, 2000).

5 Based on Marshal Semyon Timoshenko (1895-1970), commander of the Red Army at the beginning of World War II.

6 Ferriter (2005: 433) claims that during "the 1930s, 104 new plays were produced, but in the 1940s only 62, though there was still much pride in what was, after all, 'a national institution"'. Probably, theatre directors were told to ascribe to the tendency of rehearsing plays dealing purely with national Irish-related issues which might have resulted in a reduction of the number of plays.

\section{REFERENCES}

Brooker, J. (2005). Flann O'Brien. Tavistock: Northcote House.

Brooker, J. (2014). Ploughmen without Land: Flann O'Brien and Patrick Kavanagh. In J. Murphet, R. McDonald \& S. Morrell (Eds.), Flann O’Brien and Modernism (pp. 93-106). London: Bloomsbury.

Brown, T. (1981). Ireland: A Social and Cultural History, 1922-1979. London: Fontana.

Cole, R. (2006). Propaganda, Censorship and Irish Neutrality in the Second World War. Edinburgh: Edinburgh University Press.

Coulouma, F. (2011). Tall Tales and Short Stories: Cruiskeen Lawn and the Dialogic Imagination. In N. Murphy \& K. Hopper (Eds.), Flann O'Brien: Centenary Essays. The Review of Contemporary Fiction 31 (pp. 162-177). Illinois: Dalkey Archive Press.

Cronin, A. (1990). No Laughing Matter: The Life and Times of Flann O'Brien. London: Paladin.

De Paor, L. (1979). Ireland's Identities. The Crane Bag, 3, 22-29.

Ferriter, D. (2005). The Transformation of Ireland. New York, NY: Overlook. 
Flynn, C. (2017). "The Half-Said Thing": Cruiskeen Lawn, Japan and the Second World War. In R.

Borg, P. Fagan \& J. McCourt (Eds.), Flann O’Brien: Problems with Authority (pp. 71-86).

Cork: Cork University Press.

Gillespie, A. (2014). 'Banjaxed and Bewildered' Cruiskeen Lawn and the Role of Science in Independent Ireland. In R. Borg, P. Fagan \& W. Huber (Eds.), Flann O'Brien: Contesting Legacies (pp. 169-180). Cork: Cork University Press.

Girvin, B. (2006). The Emergency: Neutral Ireland, 1939-45. London: Macmillan.

Hachey, T. E. (2002). The Rhetoric and Reality of Irish Neutrality. New Hibernia Review, 6, 26-43.

Harris, T. (2016). The Catastrophe of Cliché: Karl Kraus, Cruiskeen Lawn, and the Culture Industry. The Parish Review, 3(2), 6-15.

Hopper, K. (2000). 'The Dismemberment of Orpheus': Flann O'Brien and the Censorship Code. Bells: Barcelona English Language and Literature Studies, 11, 119-131.

Hopper, K. (2009). Flann O'Brien: A Portrait of the Artist as a Young Post-Modernist. Cork: Cork University Press.

Jones, D. (2001). Censorship: A World Encyclopedia. London: Routledge.

Kennedy, M. J. (2008). Guarding Neutral Ireland: The Coast Watching Service and Military Intelligence, 1939-1945. Dublin: Four Courts Press.

Kiberd, D. (1996). Inventing Ireland: The Literature of the Modern Nation. London: Vintage.

Long, M. (2014). Assembling Flann O'Brien. London: Bloomsbury.

McCourt, J. (2014). Myles na gCopaleen: A Portrait of the Artist as a Joyce Scholar. In R. Borg, R., P. Fagan , P. \& W. Huber (Eds.), Flann O'Brien: Contesting Legacies (pp. 110-125). Cork: Cork University Press.

McMahon, P. (2008). British Spies and Irish Rebels: British Intelligence and Ireland, 1916-1945. Woodbridge: Boydell Press.

Murphy, J. A. (2000). Irish Neutrality in Historical Perspective. In G. Roberts \& B. Girvin (Eds.), Ireland and the Second World War: Politics, Society and Remembrance (pp. 9-23). Dublin: Four Courts Press.

Murphy, Neil. (2011). Flann O'Brien's The Hard Life and the Gaze of the Medusa. In N. Murphy \& K. Hopper (Eds.), Flann O'Brien: Centenary Essays. The Review of Contemporary Fiction 31 (pp.148-161). Illinois: Dalkey Archive Press.

Na gCopaleen, M. (1941a, March 17). Cruiskeen Lawn. The Irish Times, p. 6.

Na gCopaleen, M. (1941b, July 12). Cruiskeen Lawn. The Irish Times, p. 6.

Na gCopaleen, M. (1941c, August 12). Cruiskeen Lawn. The Irish Times, p. 5.

Na gCopaleen, M. (1941d, September 26). Cruiskeen Lawn. The Irish Times, p. 2.

Na gCopaleen, M. (1943, February 15). Cruiskeen Lawn. The Irish Times, p. 3.

Na gCopaleen, M. (1946, October 30). Cruiskeen Lawn. The Irish Times, p. 2.

O’Brien, Flann. (1993). The Best of Myles. London: Flamingo.

O'Brien, Flann. (1999). Flann O'Brien At War. London: Duckworth.

Ó Drisceoil, D. (1996). Censorship in Ireland, 1939-1945: Neutrality, Politics, and Society. Cork: Cork University Press. 
Ó Drisceoil, D. (2000). Censorship as propaganda: the neutralisation of Irish public opinion during the Second World War. In G. Roberts \& B. Girvin (Eds.), Ireland and the Second World War: Politics, Society and Remembrance (pp. 151-164). Dublin: Four Courts Press.

O'Halpin, E. (2008). Spying on Ireland: British Intelligence and Irish Neutrality During the Second World War. New York, NY: Oxford University Press.

Smyllie, R. M. (1946). Unneutral Neutral Eire. Foreign Affairs, 24(2), 317-326.

Taaffe, C. (2008). Ireland Through the Looking Glass: Flann O'Brien, Myles nag Copaleen and the Irish Cultural Debate. Cork: Cork University Press.

Wall, E. (1995). 'It is Midnight in Dublin and Europe is At War': Patrick Kavanagh's Poems of The Emergency. Colby Quarterly, 31(4), 233-241.

Wills, C. (2007). That Neutral Island: A Cultural History of Ireland During the Second World War. London: Faber and Faber.

Wood, I. S. (2010). Britain, Ireland and the Second World War. Edinburgh: Edinburgh University Press.

Wyse Jackson, J. (1999). Introduction. In J. Wyse Jackson (Ed.), Flann O'Brien At War (pp. 7-17). London: Duckworth.

Young, S. (1997). Fact/Fiction: Cruiskeen Lawn. In A. Clune \& T. Hurson (Eds.), Conjuring Complexities: Essays on Flann O'Brien (pp. 111-118). Belfast: Institute of Irish Studies.

Zuelow, E. (2009). Making Ireland Irish: Tourism and National Identity Since the Irish Civil War. New York, NY: Syracuse University Press. 